\title{
State-Dominated Civil Society and Migrant Children's Education in Beijing
}

\author{
Myra Pong
}

\begin{abstract}
In China, the 'tidal wave' of rural migrant workers has created unique challenges for the government, one being migrant children's education in cities. Despite central policies emphasising the roles of receiving governments and public schools in providing compulsory education for these children, many migrant children in Beijing still attend privately run, often unlicensed migrant schools. Though migrant children's education is attracting increasing government and societal attention, questions concerning the extent to which this decentralisation of responsibilities has created space for civil society in the policy process remain unexplored. This article examines the role of the civil society actors involved and draws on qualitative interviews and the author's fieldwork experience to show that their limited capacity to significantly impact the situations of these schools is shaped by a lack of state-civil society interaction, as well as limited collaboration between key civil society actors and low levels of interaction amongst the schools themselves.
\end{abstract}

In China, internal migration without a change of hukou (household registration) status ${ }^{1}$ has increased steadily since the early $1980 \mathrm{~s}$, leading to a 'tidal wave of rural migrant labor [mingong chao]' and 'the largest flow of migrant labor in history' (Roberts 1997: 250). An increasing number of these labourers take their children with them or have children in the cities (Guo 2002: 358; Kwong 2004: 1076-7). These rural migrant workers and their children (hereafter referred to as 'migrant children') tend to remain in the cities for longer amounts of time, often for over a decade (cited by Postiglione 2006: 15).$^{2}$ It was estimated that, by 2000, there were nearly 20 million children and youth under the age of 18 in China's 'floating population', that is, people residing in areas outside their place of household registration (Xinhua News Agency 2004).

According to Beijing's municipal population and family planning commission, the floating population in the capital city was about 5.4 million by 2007 , which was almost 30 per cent of the city's total population (Shan 2007). Based on the 1997 Beijing Migrant Census, approximately one-third of the city's migrants were families (Mallee 2003: 153). By the mid-2000s, it was estimated that there were around 504,000 children aged 14 and under in Beijing's floating population, an increase of about 310,000 since 2000 (Zhai et al. 2007; Duan and Yang 2008: 23).

The rise in the number of migrant families in cities like Beijing has created unique challenges for the Chinese government, one being educational provision for migrant children. Central policies since the early 2000s have called for the primary role of receiving governments and public primary and middle schools in providing education for these children. Yet many migrant children in Beijing still attend privately run migrant schools, which are poor in quality and often unlicensed. While the problems of these schools have been garnering an increasing amount of government and societal attention since the mid- to late 1990 s, there has been little analysis of the policy environment in this area and the role of civil society in particular.

Since the late $1990 \mathrm{~s}$, a range of actors outside the government have become involved in migrant children's education in Beijing. They include academics and researchers, the media, university student organisations, NGOs, migrant 
school principals' and teachers' associations, and parent activists. Understanding of the role of these actors and their capacity to impact migrant schools, however, has been limited, and key questions remain unexplored. Are these actors able to influence the situations of migrant schools in Beijing either directly or through engagement with the government? What are the main constraints faced, and what are the implications for these schools and the future of migrant children's education in the city? In light of growing discussion about civil society in China (e.g. Howell 2007; Cheng et al. 2010), exploring these questions will not only enhance the understanding of the impact of state-civil society relations on migrant children's education in Beijing, but it will also help in identifying more targeted measures to improve the situations of these schools and their students.

This article starts by providing useful background information regarding migrant schools in Beijing and the municipal government's policy response, followed by a discussion of civil society in social welfare provision in China. The rest of the article examines the involvement of civil society actors in migrant children's education in Beijing and illustrates that their capacity to have a substantial impact remains low, with implications for the amount of support received by migrant schools and their students and subsequently broader trends in social stratification. It draws on evidence from qualitative interviews conducted in 2009-10 and various aspects of my fieldwork experience to highlight three areas in which a lack of interaction has inhibited the capacity of actors outside the government - including academics and researchers - to improve the situations of migrant schools in Beijing: a general lack of state-civil society interaction; limited collaboration between key civil society actors involved; and low levels of interaction amongst many migrant schools themselves. ${ }^{3}$

\section{Migrant children's education in Beijing}

The surge in the number of school-aged migrant children in Chinese cities, particularly since the early to mid-1990s, has increased the urgency of issues concerning the provision of basic education for this group (Lu and Zhang 2004: 65). China's Compulsory Education Law (1986) stipulated that the government would provide nine years of education to all children at the primary and middle school levels free of tuition.
Local governments, however, were only in charge of providing education to children with local hukou (Han 2001: 17; Kwong 2006: 168-9).

Under these circumstances, migrant parents began to find other ways to educate their children in the early to mid-1990s. This involved tutoring or teaching classes in places such as vegetable sheds and shanties and, later on, migrants' homes and deserted buildings (Han 2001: 1-5). The number of migrant schools grew over time, particularly in large cities like Beijing, Shanghai, and Guangzhou (Project Team on Rural Labor Migration 2001: 119). These schools were created as a 'self-help' (zili jiuji) mechanism in a context in which migrant workers were unable to meet the requirements for their children to attend state-run public schools, including the payment of high fees (see Han 2001: 1-4). ${ }^{4}$

At first, the central government did not take an official position towards these migrant schools and adopted a strategy of 'do not prohibit, do not recognise, let it run its course' (bu qudi, bu chengren, zisheng zimie) (Han 2001: 3; Kwong 2004: 1079). Its earliest measures towards migrant children's education, adopted in 1996 and 1998, stipulated that migrant children could be educated as 'temporary students' (jiedusheng) in public schools in receiving areas, but this would depend on an application process and various conditions, making enrolment difficult. ${ }^{5}$ The initial lack of government action towards migrant schools, along with barriers to public school education, created space for migrant schools to rapidly grow in number in the midto late 1990s. It was estimated that there were about 350 migrant schools in the city by late 2002 (Han 2003: 402).

In 2001, however, in line with a central-level policy shift towards improving the treatment of migrant workers in the early $2000 \mathrm{~s},{ }^{6}$ the central government adopted a policy of 'two priorities' (liangweizhu) towards migrant children's education, where the two areas of focus would be management by receiving governments and education in public primary and middle schools. Policies since then have also called on receiving governments to increase their support for migrant schools. This decentralisation of responsibilities, while a significant step forward, created space for different policy approaches at the local level. In the case of Beijing, this has meant that many 
Poor physical conditions

Low quality of teaching

Instability

Difficulties acquiring legal status
- The conditions are poor, and most migrant schools lack adequate supplies and equipment

- Teachers often lack basic training and experience

- Teacher turnover is high

- Migrant schools are frequently vulnerable to being shut down by the government and demolished

- Migrant schools face difficulties getting government licences

- As of mid-2010, only 66 of the city's over 300 migrant schools were licensed

Source Author's fieldwork (2009-10). See Han (2001) and Lu (2007) for further discussion of migrant schools in Beijing during the 1990s.

migrant children continue to attend privately run migrant schools. Yet nearly two decades after their first appearance in the city, these schools are still poor in condition, offer low quality education, remain vulnerable to government closures and demolition, and often lack state recognition (see Table 1). According to Lai et al. (2012: 15-16), the quality of teaching and facilities at migrant schools in Beijing even lags behind rural schools. Nevertheless, they have become a more feasible option than public school education for many migrant children due to factors like flexible enrolment procedures and low fees and remain a critical source of education for these children (Kwong 2006: 172; Chen and Liang 2007: 125-6).

My review of the Beijing municipal policies on migrant children's education shows that they do reiterate many of the basic sentiments expressed in the central policies, including migrant children's right to education and the need to treat migrant and local children equally.

However, the decentralisation of responsibilities called for by the policy of 'two priorities' has essentially allowed Beijing - the nation's political centre - to adopt an approach based on its own concerns about population growth and social instability. As Wang (2008: 692) explains:

[The Beijing] municipal government takes a very cautious attitude towards educational provision for migrants, as there is anxiety that easing the situation will accelerate the growth of migrants and will increase pressure to make it easier to obtain urban social rights. The policymakers are particularly concerned with the image of the capital and generally consider migrants as a disproportionate source of social and civic problems.
These concerns have had major consequences for the situations of migrant schools and their students, and it was clear during my fieldwork that these schools, particularly unlicensed ones, have received little support from the municipal government. ${ }^{7}$ Not only have there been repeated efforts to shut down unlicensed migrant schools in the name of safety and public security, but the city's pursuit of urban development has also meant that frequent rounds of demolition continue to threaten the survival of licensed and unlicensed migrant schools and the migrant enclaves in which they are usually located. Educational provision for migrant children by these schools has therefore become an increasingly urgent issue. Important questions then arise about the extent to which decentralisation has created space for actors outside the government to impact the situation and what that ultimately means for the situations of migrant schools in the capital city.

\section{Decentralisation and civil society in social welfare provision in China}

Decentralisation is frequently discussed as a key factor influencing policy processes (e.g. Blaikie and Soussan 2001). In developing countries and transition economies, the term is often used to refer to the actual transfer of decision-making power to the local levels. In countries where centralised control has been long-established (such as China), it usually refers to the transfer of responsibilities when implementing policies at lower levels. Though decentralisation is often seen as a way of increasing accountability and the efficiency of governments (Bardhan 2002: 185-6), there is growing discussion of its complex effects in the literature on policy processes. It can, for example, increase the 
number of stakeholders and create space for civil society to influence the policy process (King and Cordeiro Guerra 2005: 200).

The notion of 'civil society' is highly complex and difficult to analyse, and its meaning has been subject to much debate. According to Malena and Heinrich (2007: 338): '[C] ivil society can be broadly understood as the space in society where collective citizen action takes place'. Examining the impact of civil society on social welfare provision and especially policy - including comparing its role across different countries - is therefore also extremely difficult due to 'the current lack of consensus about its nature, and the enormous diversity in how it is understood and manifested in different contexts around the world' (Malena and Heinrich 2007: 339). Indeed, civil society actors can play a range of roles, and their policy impact can vary between policy areas and across and within different localities, making generalisations problematic (Edwards et al. 1999: 130; Malena and Heinrich 2007: 341).

In China, decentralisation has created room for civil society involvement in the delivery of services since the 1980s (Davis 1989; Teets 2008: 7-8). The 1990s in particular witnessed a major increase in the number of civil society associations working in service provision for marginalised groups including workers, women, children, the poor, and people with disabilities (Howell 2007: 19). ${ }^{8}$ State-civil society relations in social welfare provision in China are complex, and government actors at different levels may adopt different strategies towards civil society such as indifference, tolerance, encouragement, and endorsement. These strategies are often affected by concerns about political and social instability and can vary across localities and policy areas (Cheng et al. 2010: 1104). For instance, issues concerning gender are usually seen as being less sensitive than those concerning labour; thus, 'just as attempts to organize around labour point to the boundaries of Party-state tolerance for civil society, organizing around gender can indicate how wide the space for organizing can be pushed' (Howell 2003: 207). Cheng et al. (2010: 1089-90) argue the following for the case of many labour NGOs in China:

In the eyes of local governments, it appears rational and advantageous to provide these labour NGOs with a certain degree of political support to promote social harmony and justice;... However, these labour NGOs do not have legal status and supporting them openly carries political risk. This is why local governments tend to ignore them and maintain a wait-and-see attitude. In other words, local governments avoid political risk, adopting a neutral and defensible position while trying to take advantage of the NGOs' help.

Ultimately, the extent to which civil society actors in China are able to build relationships with the government has become a key factor affecting their involvement in social welfare provision and subsequently the services and support available to the groups they serve, making closer examinations of their role in different policy areas and local contexts critical (Howell 2003; Cheng et al. 2010). Though there has been growing interest in the role of civil society in areas like gender and labour, few studies have explored such dynamics for migrant children's education, a policy area that is itself closely tied to issues of labour. ${ }^{9}$

Yet civil society actors have become increasingly involved in migrant children's education in Beijing over the last decade and a half, raising important questions about their role. Drawing on interviews and aspects of my fieldwork experience, the rest of this article sheds light on the nature of civil society involvement in migrant children's education in the city, including the extent to which the key actors involved are able to interact with and attain support from the government. ${ }^{10}$ It illustrates that, due largely to the local government's concerns about population growth and social instability, state-civil society interaction in this area has been very limited. Along with low levels of collaboration among key civil society actors involved, as well as limited interaction amongst many migrant schools, this has greatly restricted the capacity of civil society to have a large-scale impact on the situations of migrant schools and their students.

\section{Civil society involvement in migrant children's education in Beijing}

During much of the 1990s, the Chinese government saw migrant schools as illegal entities, and knowledge about them was limited (Han 2001: 2). Though still vulnerable to government closures, most migrant schools in Beijing no longer operate as 'underground' 


\begin{tabular}{|c|c|c|}
\hline Actor & Period of involvement & General nature of involvement \\
\hline Academics and researchers & Since the mid-1990s & $\begin{array}{l}\text { Conduct research, usually on the situation of migrant } \\
\text { schools; occasionally submit their findings to the } \\
\text { government } \\
\text { Organise forums with other actors involved } \\
\text { Create programmes or organisations to provide services } \\
\text { for migrant schools and their students }\end{array}$ \\
\hline Media & Since the mid-1990s & $\begin{array}{l}\text { Report on key developments, including the demolition of } \\
\text { migrant schools } \\
\text { Publicise NGO programmes and events }\end{array}$ \\
\hline $\begin{array}{l}\text { University student } \\
\text { organisations }\end{array}$ & Since the late 1990s & $\begin{array}{l}\text { Volunteer at migrant schools, either independently or } \\
\text { through NGOs, by teaching classes, tutoring, organising } \\
\text { events, and donating supplies }\end{array}$ \\
\hline NGOs & $\begin{array}{l}\text { Mainly since the } \\
\text { mid-2000s }\end{array}$ & $\begin{array}{l}\text { Provide services to particular migrant schools and their } \\
\text { students (e.g. tutoring and teacher training) and organise } \\
\text { programmes and events }\end{array}$ \\
\hline $\begin{array}{l}\text { Migrant School Principals' } \\
\text { Association }\end{array}$ & Since 1999 & $\begin{array}{l}\text { Serves as a forum for principals to share information } \\
\text { about key problems and developments }\end{array}$ \\
\hline $\begin{array}{l}\text { Migrant School Teachers' } \\
\text { Association }\end{array}$ & Since 2009 & $\begin{array}{l}\text { Serves as a forum for teachers to exchange knowledge } \\
\text { and address issues like how to seek equal treatment as } \\
\text { public school teachers and improve their teaching ability }\end{array}$ \\
\hline Migrant parent activists & $\begin{array}{l}\text { Since the mid- to } \\
\text { late } 2000 \text { s }\end{array}$ & - Organise petitions and rallies \\
\hline
\end{tabular}

Source Author's fieldwork (2009-10).

schools. This rise in visibility can largely be seen as an outcome of the work of civil society. Indeed, the discovery of the existence of migrant schools in Beijing during the mid-1990s is commonly attributed to a local researcher, who brought the issue to the attention of the media and subsequently government and society. Since then, a range of other actors have become involved (see Table 2), in line with the general increase in civil society involvement in social welfare provision discussed above. Based on fieldwork, the involvement of these actors is driven by a combination of three key motives: to provide support directly to migrant schools and their students and teachers, to raise awareness about the problems of these schools, and to influence government and policy (see Pong 2012).

During fieldwork, I encountered a basic challenge in assessing the extent to which these actors have been able to, through their work and relationships, impact migrant children's education and address the problems of migrant schools. There is an overall lack of consistent, upto-date data on migrant children and migrant schools in China. For example, based on data from the 1997 Beijing Migrant Census, it was estimated that 88 per cent of the city's migrant children were enrolled in school (Guo 2002: 357). However, another estimate suggested that only 40 per cent of the city's migrant children between the ages of five and 12 were attending school in 1995, compared to 100 per cent of local children in the same age group (cited by Solinger 1999: 266). Moreover, while the China News Agency stated that 12.5 per cent of Beijing's migrant children were enrolled in school in 2001, the Xinhua News Agency claimed in 2002 that nearly 80 per cent of the city's migrant children were in public schools (cited by Kwong 2006: 169). Furthermore, official data that is publicly available, including that in the annual education yearbooks, does not generally include figures on migrant children or migrant schools. The terms 'children of the floating population' (liudong ertong) and 'migrant workers' children' 
'[Civil society] is becoming more and more involved... [but] its impact is not great' (HL1P1).

- 'If you rely on [other actors] to try to resolve the problems, the impact will be limited.... The government has the real strength, so we have to rely on the government' (HL2P1).

- '[Actors like] NGOs come and do a little tutoring and provide some help to the students, but they cannot resolve the basic problems' (HU1P1).

- At one licensed school, the principal expressed that the school has had extremely little interaction with actors like NGOs, academics, and the media, and has to instead rely on the local government for any support or assistance (FL1P1).

- 'These actors don't have much of an impact [on our school]. Researchers may come and conduct studies, but some are objective, and [their research] won't immediately have an impact' (PU1P1).

Source Author's fieldwork (2009-10).

(nongmingong zinü) are also frequently used inconsistently and unclearly in Chinese documents. The latter is technically a subset of the former, which also includes children who do not possess the local city's hukou but are not the children of rural migrant workers.

This lack of reliable data on migrant children and their educational situations reflects to a large extent the mobile nature of the rural migrant population and the challenges of establishing a sampling frame for this segment of the population (Hannum et al. 2010: 145). It has limited the capacity of researchers to build a more comprehensive understanding of the scale of educational exclusion among these children, and it affected my own capacity to evaluate the extent to which civil society is able to positively impact their educational opportunities and outcomes.

Despite this basic difficulty, I was able to build an understanding of civil society involvement in migrant children's education and its impact on migrant schools by conducting qualitative interviews with actors like NGOs and researchers, as well as migrant school principals and teachers. Evidence from these interviews indicates that the overall impact of civil society on the situations of migrant schools and their students remains limited. An exception can be found in the events following the promulgation of the 'Notice of the General Office of the Beijing Municipal People's Government on the Work of Strengthening the Safety of NonApproved Self-Run Migrant Schools' in July 2006. The document stated that most unlicensed migrant schools offer poor quality education and pose security risks in areas like infrastructure, fire safety, and health and sanitation. It therefore proposed that district/county governments set deadlines for improvement and shut down substandard schools by the end of September 2006. What ensued was viewed by many principals, NGOs, and others as an attempt to close as many migrant schools as possible before the 2008 Beijing Olympics. It generated opposition, including criticism from the principals themselves, who appealed to actors such as NGOs and the media for support. These efforts arguably played a role in putting pressure on the municipal government, which did eventually cancel the decision. Such occurrences, however, have been rare, and there was general agreement among my interviewees, including the majority of principals interviewed, that civil society has ultimately had little impact on migrant schools (see Table 3).

Important questions then arise concerning the reasons behind this limited impact. Based on evidence from interviews, as well as aspects of my fieldwork experience, there are three key areas in which a general lack of interaction has greatly inhibited civil society's capacity to improve the situations of migrant schools in Beijing. First, there is a general lack of interaction between government and civil society actors in this policy area. Though there are certainly exceptions, each set of actors mentioned above faces basic obstacles in building relationships with the local government in Beijing (see Table 4). These difficulties stem largely from a general unwillingness among government actors in Beijing to provide substantial support for civil society's work in an area that is, in their view, closely linked to population growth and social instability. Such concerns have led the municipal government to, 
Academics and researchers

- Most academics and researchers in the sample expressed having very limited interaction with the government. According to an established researcher in the sample, the government consulted academics and researchers more frequently in the early to mid-2000s due to a lack of knowledge about the subject. Since then, the level of interaction has somewhat declined.

Media

- Though the media have played a role in bringing issues like demolition to the public's attention, their capacity to build relationships with the government and generate change in the area remains low. For example, media coverage was unable to stimulate change when several district governments closed over 30 migrant schools in 2010.

University student organisations

NGOs

Student groups focus primarily on providing services to migrant schools directly and lack the channels to interact with local government actors.

- Most NGOs involved lack the channels to build close working relationships with local government actors. The majority of the NGOs in my sample lacked relationships with the municipal and district education commissions. Only two had had limited contact with municipal-level officials (e.g. in the labour bureau).

\begin{tabular}{ll}
\hline $\begin{array}{l}\text { Migrant School Principals' } \\
\text { Association }\end{array}$ & Past attempts to express its views to the government have been unsuccessful. \\
& For example, it has occasionally submitted reports to the municipal \\
& government, but such efforts have not resulted in much action. \\
\hline Migrant School Teachers' & Though it has built relationships with NGOs, local media, and academics, it \\
Association & has not been able to interact with the government and lacks direct channels \\
& to impact policy.
\end{tabular}

Migrant parent activists

- Only a small number of parents with children in public schools have adopted action. To date, they have organised petitions and rallies to include migrant children in the computerised lottery system for entry into local public middle schools and to cancel the requirement for migrant children to return to their place of hukou registration for the university entrance exam. Despite these efforts, local government actors generally avoid interacting with them.

Source Author's fieldwork (2009-10).

for the most part, either disregard or tolerate their existence, and decision-making in this area continues to be government-controlled. This overall lack of state-civil society interaction has had major consequences for their capacity to influence policy and improve the situations of migrant schools in the city.

As a result, one of the fundamental challenges encountered by those doing field research on migrant children's education in China particularly those engaging with policy issues involves the difficulties of accessing government actors. ${ }^{11}$ This is perhaps a particular problem in Beijing, where the municipal government views migrant children's education as being closely linked to issues of social stability. During my fieldwork, for example, I was only able to access certain district-level officials through a local university. Though this affected the depth of my knowledge about internal decision-making at the various levels of government, I was able to draw on interviews with other actors like principals and policy materials collected to supplement the information obtained from the government interviews and create a stronger understanding of the local policy environment.

Second, there is limited collaboration amongst key groups of civil society actors themselves, as well as between them and many migrant schools, with additional consequences for their capacity to improve the situations of the schools. There is, for instance, very little interaction between the principals' and teachers' associations. Interaction between academics and researchers and many migrant schools is also limited, and parents with children in these schools frequently lack the 
channels to interact with actors like researchers, NGOs, and the media. There are exceptions; for example, many researchers and NGOs involved do collaborate and exchange information and ideas with each other. Overall, though, there is still a lack of interaction in key areas in which closer collaboration could more greatly benefit migrant schools and their students.

\section{These limited levels of collaboration reflect a} tendency among some actors to focus their already limited resources on providing services directly to particular migrant communities and schools. But they are also due in part to the existence of tensions between certain actors. For example, the lack of interaction between the principals' and teachers' associations stems, at least in part, from concerns among many principals that their teachers will gain too much power and make demands they are unable to meet. In addition, a common perception, particularly among academics and researchers and certain NGOs, is that migrant school principals run their schools like businesses. As Wang (2008: 693) points out: 'It is a matter of growing concern that many [migrant schools] are run essentially for profit rather than to provide basic education services'. This view - mainly based on the unconfirmed observation of many academics and researchers that these principals pocket a significant amount of the money earned through tuition after paying teachers' salaries and other expenses like rent - can then influence the views of government actors, who may consult these academics and researchers. It can also affect the views of the principals themselves, and I noticed an awareness of this perception during a lot of my own conversations with principals and therefore had to position myself during these interviews as someone who was aware of their concerns and committed to identifying ways to improve the situations of their schools. Thus, even though many principals continue to view building relationships with academics and researchers as an opportunity to help their schools, this perception has inhibited the development of close relationships between certain key academics and researchers and government actors on the one hand and migrant schools on the other. Such examples help shed additional light on the complex factors impacting civil society's involvement in this area, with implications for the capacity of these actors to collaborate and generate change.
Third, despite the existence of a migrant school principals' association, there is still a limited amount of interaction amongst many migrant schools, making it more difficult for actors such as researchers to gain widespread access to them. Due to their high mobility and the fact that most lack government licences, there is no official, comprehensive list of migrant schools in Beijing, and actors like researchers and NGOs must rely on other channels to gain access to them. One channel commonly used involves asking principals to provide contact information for other schools. The low level of interaction amongst many principals, however, has meant that some schools are left out when this channel is used. Ultimately, the extent to which migrant schools in Beijing receive external support and assistance is often closely related to the reputations of the school and the principal, and researchers and NGOs frequently recommend schools to others based on these reputations. As a result, migrant schools that are more isolated may not receive the external support and assistance they and their students need; for instance, principals I interviewed at schools in Fengtai, one of the city's poorer districts, expressed having had little to no previous contact with academics and researchers. This has further implications for the impact of civil society on the overall situation of these schools.

Here, my own fieldwork experience can help shed light on the difficulties faced. While gaining access to actors like researchers and NGOs was relatively more straightforward, several obstacles were encountered in accessing migrant schools. Many principals, for example, were unable to provide me with the locations or contact details of nearby migrant schools. In addition, due to the basic difficulties of counting and keeping track of these schools, the two unofficial contact lists of migrant schools I was able to access included information that was often incomplete and/or outdated. I therefore had to rely on multiple channels to access the schools, including sources like well-connected principals, researchers, and NGOs; in other words, the relationships I was able to build were critical in this process.

Still, even when accurate contact details for a school were obtained, its inclusion in the sample was subject to the principal's consent. Several principals I contacted declined to participate, saying, for instance, that they were too busy or 
that their school was about to be closed or demolished. Moreover, while most interviewees were willing to talk with me about their schools, some were more reluctant. There was a general view among principals and teachers interviewed that the local government is focused more on issues of public security and safety than on improving the schools and that civil society actors therefore lack the power to generate change. One result has been a growing sense of hopelessness among a proportion of these principals and teachers. Some, for instance, asserted that research and media coverage on the subject are essentially useless and will not lead to positive change for their schools or the larger problems of migrant children. The existence of such feelings was an obstacle that affected my capacity as a researcher to acquire information at those particular schools.

In addition, even though I was residing in one of the selected districts, travelling to migrant schools was often difficult and time-consuming, particularly as a doctoral student. Making trips to these schools would commonly involve first taking the subway, followed by at least one or two bus rides, and, since migrant schools are usually located in more remote areas, buses to these areas are sometimes less frequent. The final leg of the trip would involve navigating through the migrant village by foot, sometimes with multiple stops to ask for directions since the schools can be difficult to find. As a result, it was necessary to allow two or more hours of travel time each way for migrant school visits. Based on interviews with actors like NGOs and university student groups, this issue of distance and travel time has become another key factor affecting the number of civil society actors working with schools in particular parts of the city, as well as the total number of schools any particular actor is able to work with, with additional consequences for civil society's impact in this area.

\section{Implications for migrant children's education and the future of state-civil society relations}

In light of the overall lack of government and policy support for migrant schools in Beijing and the fact that migrant children's education continues to be seen by the government as a delicate subject, the increased involvement of civil society is notable, and there are reasons to be hopeful about its role in the future. Civil society actors have, thus far, played a significant role in bringing more attention to the policy area, evidenced, for instance, by increased international media coverage, and actors like NGOs and university student groups can have important impacts on the particular schools or students they work with. The work these actors do is of symbolic and political importance; that is, by working in an area such as migrant children's education, they highlight the potential limitations of government authority and subsequently also the possibilities for broader sociopolitical reform (see Howell 2003: 208).

However, the above discussion illustrates that, on the whole, these actors have not been able to have a large-scale impact on the situations of migrant schools in Beijing, with serious implications for the future of migrant children's education in the city. This is largely due to the low level of government support for their work and limited state-civil society interaction, which, as previously mentioned, is a key factor shaping civil society's role in social welfare provision in China. Evidence from interviews shows that the Beijing municipal government has not taken major steps to control or absorb the actors discussed above or given them substantial support or recognition. Instead, it has mainly tolerated those actors that refrain from openly opposing government objectives (including university student groups and many NGOs) and ignored those that are considered to be more of a potential threat to policy goals (mainly the principals' and teachers' associations and parent activists). While coverage of key developments and issues by independent and state-run media has, on certain occasions, helped put pressure on local government actors, the media's capacity to stimulate larger policy change is still low. The actors in the strongest position to generate change are academics and researchers, but their contact with the government remains limited.

Overall, local government actors in Beijing continue to view migrant children's education as a policy area with ramifications for population growth and social stability (Wang 2008: 692) and, as shown in Table 4, have been able to restrict the influence of civil society actors by avoiding close interaction with them. Limited collaboration between certain groups of civil society actors and low levels of interaction amongst many migrant schools have also inhibited the capacity of these actors to generate larger change. Further 
complicating the situation is the emergence of variation between district-level policy

implementation, which has had consequences for where in the city these actors tend to work and the amount of external attention and support migrant schools in different parts of the city receive (see Pong 2012).

Aspects of my fieldwork experience help shed additional light on the types of obstacles these actors - academics and researchers included continue to encounter, as well as the larger problems shaping their role in the policy area. The difficulties I faced as a researcher, particularly in acquiring data on migrant children and accessing government actors and migrant schools, provide evidence to support that there is a fundamental lack of interaction, collaboration, and exchange of knowledge in this area, both between state and societal actors and amongst societal actors themselves. Ultimately, the continued existence of these challenges makes examining the extent to which civil society is able to impact migrant children's education all the more significant.

This article illustrates the complex, political nature of migrant children's education in Beijing. Given that the policy area is closely related to issues concerning migration and labour - an area of welfare provision in China in which civil society has often had little impact on policy (Cheng et al. 2010) - it is perhaps not surprising that the actors examined in this article have been unable to play a major role in the local policy process. The above discussion provides an example of a case in which the role and impact of civil society actors involved in welfare provision are heavily shaped by the extent to which the actors are viewed by the local government as representing issues that could generate social instability, consistent with the arguments raised by Howell (2007: 19) and Cheng et al. (2010: 1089-90, 1104). It therefore fills important gaps in the knowledge of the local policy environment in this area, including which actors are involved and why, and strengthens the understanding of the complex factors shaping the amount of support migrant schools receive. It also sheds further light on some of the broader themes explored in this issue, including the role of actors and agency (see Denskus, this IDS Bulletin).

It is possible for civil society actors to have an impact on the situations of migrant schools in Beijing, the events of mid-2006 discussed earlier being an example. Yet such occurrences have been rare, and serious obstacles remain. My findings, along with the challenges I encountered as someone doing field research in the area (particularly as one engaging with policy issues), show that there is an urgent need for formal change, with a focus on how the local government and civil society can work towards meeting the needs of migrant schools and their students. Though the complex nature of the policy area means that any change will require time, the situation in Beijing calls for a greater level of collaboration, in which the government should take advantage of the knowledge, networks, and skills civil society actors have to offer. This effort can begin with academics and researchers, who are best positioned to impact policy and can serve as a link between the various actors. Here, the tensions arising from the continued perception of migrant school principals as profit-seeking individuals remain an obstacle, but the hope is that this will become less and less of a barrier with changes like more regular principal training and more systematic management of the schools by the government. Local government actors should see developing these relationships as a way to enhance their reputation and also lessen their own burden, since civil society can be a source of additional resources. For civil society actors, these relationships would boost their legitimacy, as well as improve their understanding of the policy process and subsequently their capacity to generate reform. Increased collaboration would ultimately bring about a much needed change in the implementation process and strengthen the ability of the government and civil society to improve the educational situations of migrant children in the city. 


\section{Notes}

1 The hukou (household registration) system divides citizens by their place and type of registration (rural or urban, agricultural or non-agricultural).

2 In contrast, children of migrant workers who stay in rural areas, usually under the care of grandparents, are known as 'left-behind children'.

3 My doctoral thesis analyses the provision of compulsory education for migrant children in Beijing, with a focus on policy implementation at the municipal and district levels and how it has shaped the situations of migrant schools and their students directly and through civil society. Interviews were conducted with local government officials; migrant school principals and teachers; migrant families; and civil society actors, who were accessed primarily through key contacts and local symposiums and conferences.

4 Though the Compulsory Education Law stated that primary and middle school education would be free, urban public schools would usually charge migrant children fees such as temporary schooling fees (jiedufei) and sponsorship fees (zanzhufei) (Han 2001: 4).

5 See Pong (2012) for an examination of the central and Beijing municipal policies on migrant children's education.

\section{References}

Bardhan, Pranab (2002) 'Decentralization of Governance and Development', Journal of Economic Perspectives 16.4: 185-205

Blaikie, Piers and Soussan, John (2001) Understanding Policy Processes, Livelihood-Policy Relationships in South Asia Working Paper 8, Leeds: University of Leeds, www.york.ac.uk/ inst/sei/prp/pdfdocs/2_livelihoods.pdf (accessed 10 May 2009)

Chen, Yiu Por and Liang, Zai (2007)

'Educational Attainment of Migrant Children: The Forgotten Story of China's Urbanization', in Emily Hannum and Albert Park (eds), Education and Reform in China, Oxford: Routledge

Cheng, Joseph Y.S.; Ngok, Kinglun and Zhuang, Wenjia (2010) 'The Survival and Development Space for China's Labor NGOs: Informal Politics and its Uncertainty', Asian Survey 50.6: 1082-106

Davis, Deborah (1989) 'Chinese Social Welfare: Policies and Outcomes', The China Quarterly 119: 577-97
6 See Pong (2012) for an overview of central policies towards rural migrant workers over time.

7 Based on fieldwork, the two main forms of support provided by the Beijing municipal government for licensed migrant schools are a subsidy for students (80 RMB, or about $£ 8$, per student per term at the primary school level and $130 \mathrm{RMB}$, or about $£ 13$, per student per term at the middle school level) and new desks, chairs, podiums and lights.

8 See Howell (2007: 17-20) for a discussion of the political and economic factors behind the rise in the number of such associations.

9 Perhaps the only exception is Kwong (2004), which was written prior to the emergence of actors including many of the NGOs now involved.

10 These characteristics are primarily adapted from a framework discussed by Malena and Heinrich (2007: 341).

11 In China, such access is frequently limited due to the closed nature of policy deliberations and decision-making (Howell 2003: 198), though this can vary depending on factors like the perceived sensitivity of the subject and the nature of the research.

Duan, Chengrong and Yang, Ge (2008) 'Woguo Liudong Ertong Zuixin Zhuangkuang: Jiyu 2005 Nian Quanguo 1\% Renkou Chouyang Diaocha Shuju de Fenxi' ['Study on the Latest Situation of Floating Children in China'], Renkou Xuekan [Population Journal] 6: 23-31

Edwards, Michael; Hulme, David and Wallace, Tina (1999) 'NGOs in a Global Future: Marrying Local Delivery to Worldwide Leverage', Public Administration and Development 19.2: 117-36

Guo, Fei (2002) 'School Attendance of Migrant Children in Beijing, China: A Multivariate Analysis', Asian and Pacific Migration Journal 11.3: 357-74

Han, Jialing (2003) 'Beijingshi: "Dagong Zidi Xuexiao" de Xingcheng, Fazhan yu Weilai' ['The Formation, Development, and Future of Migrant Schools in Beijing'], in Xiaobing Sun (ed.), Zhongguo Minban Jiaoyu Zuzhi yu Zhidu Yanjiu [Research on the Organisation and System of Private Education in China], Beijing: Zhongguo Qingnian Chubanshe [China Youth Press] 
Han, Jialing (2001) 'Beijingshi Liudong Ertong Yiwu Jiaoyu Zhuangkuang Diaocha Baogao' ['Report on the Investigation of the Compulsory Education Situation of Children of the Floating Population in Beijing'], Qingnian Yanjiu [Youth Studies] 8 and 9: 1-7, 10-18

Hannum, Emily; Wang, Meiyan and Adams, Jennifer (2010) 'Rural-Urban Disparities in Access to Primary and Secondary Education under Market Reforms', in Martin King Whyte (ed.), One Country, Two Societies: RuralUrban Inequality in Contemporary China, Cambridge MA: Harvard University Press Howell, Jude (2007) 'Civil Society in China: Chipping Away at the Edges', Development 50.3: 17-23

Howell, Jude (2003) 'Women's Organizations and Civil Society in China: Making a Difference', International Feminist Journal of Politics 5.2: 191-215

King, Elizabeth M. and Cordeiro Guerra, Susana (2005) 'Education Reforms in East Asia: Policy, Process, and Impact', in World Bank (ed.), East Asia Decentralizes: Making Local Government Work, Washington DC: World Bank, http://siteresources.worldbank.org/INTEAPD EGEN/Resources/dc-full-report.pdf (accessed 4 November 2008)

Kwong, Julia (2006) 'The Integration of Migrant Children in Beijing Schools', in Gerard A. Postiglione (ed.), Education and Social Change in China: Inequality in a Market Economy, Armonk NY: M.E. Sharpe, Inc.

Kwong, Julia (2004) 'Educating Migrant Children: Negotiations between the State and Civil Society', The China Quarterly 180: 1073-88

Lai, Fang; Liu, Chengfang; Luo, Renfu; Zhang, Linxiu; Ma, Xiaochen; Bai, Yujie; Sharbono, Brian and Rozelle, Scott (2012) Private Migrant Schools or Rural/Urban Public Schools: Where Should China Educate its Migrant Children?, REAP Working Paper 224, Stanford: Stanford University, Rural Education Action Project, http://iis-db.stanford.edu/pubs/23180/migrant _paper_final_sdr_fang_acm_sdr_march26_ sdr.pdf (accessed 3 August 2012)

Lu, Shaoqing (2007) Liushou Haishi Liudong? 'Mingong Chao' Zhong de Ertong Yanjiu [Left Behind or Migration? An Empirical Study on Children of Rural Migrants], Beijing: Zhongguo Nongye Chubanshe [China Agriculture Press]

Lu, Shaoqing and Zhang, Shouli (2004)

'Urban/Rural Disparity and Migrant Children's Education: An Investigation into
Schools for Children of Transient Workers in Beijing', Chinese Education and Society 37.5: 56-83 Malena, Carmen and Heinrich, Volkhart Finn (2007) 'Can We Measure Givil Society? A Proposed Methodology for International Comparative Research', Development in Practice 17.3: 338-52

Mallee, Hein (2003) 'Migration, Hukou and

Resistance in Reform China', in Elizabeth J.

Perry and Mark Selden (eds), Chinese Society:

Change, Conflict and Resistance, 2nd edition,

London: RoutledgeCurzon

Pong, Myra (2012) 'Understanding Migrant Children's Education in Beijing: Policies, Implementation, and the Consequences for Privately-Run Migrant Schools', PhD thesis, IDS, Brighton

Postiglione, Gerard A. (2006) 'Schooling and Inequality in China', in Gerard A. Postiglione (ed.), Education and Social Change in China: Inequality in a Market Economy, Armonk NY: M.E. Sharpe, Inc.

Project Team on Rural Labor Migration (2001) 'Rural Labor Migration in China: Retrospect and Prospect', in Ford Foundation (ed.), Labor Mobility in China: A Review of Ford Foundation Grantmaking 1997-2001, Beijing: Ford Foundation

Roberts, Kenneth D. (1997) 'China's "Tidal Wave" of Migrant Labor: What Can We Learn from Mexican Undocumented Migration to the United States?', International Migration Review 31.2: 249-93

Shan, Juan (2007) 'Migrant Population Swelling in Beijing', China Daily, 5 December, www.chinadaily.com.cn/china/2007-12/05/ content_6298917.htm (accessed 25 April 2009)

Solinger, Dorothy J. (1999) Contesting Citizenship in Urban China: Peasant Migrants, the State, and the Logic of the Market, Berkeley CA: University of California Press

Teets, Jessica (2008) 'Improving Governance in China: The Role of Civil Society in Local Public Policy', paper presented at the Midwest Political Science Association National Conference, Chicago IL, April, www.allacademic.com/meta/p_mla_apa_resea rch_citation/2/6/7/4/9/p267492_index.html (accessed 4 November 2008)

Wang, Lu (2008) 'The Marginality of Migrant Children in the Urban Chinese Educational System', British Journal of Sociology of Education 29.6: 691-703 
Xinhua News Agency (2004) Foundation to Fund Education of Migrant Workers' Children, 14 January, www.china.org.cn/english/culture/ 84631.htm (accessed 6 April 2012)

Zhai, Zhenwu; Duan, Chengrong and Bi, Qiuling (2007) 'Beijingshi Liudong Renkou de Zuixin
Zhuangkuang yu Fenxi' ['The Floating Population in Beijing: An Update'], Renkou Yanjiu [Population Research] 31.2: 30-40 